\title{
You Can't Move All Your Hotels to Mexico: Unions and the Hospitality Industry
}

\author{
David Sherwyn and Paul E. Wagner
}

For many years, most hotel workers were not a particular focus of the labor movement. Traditionally, hotel employees were not highly paid, often worked for tips, and did not stay in bargaining-unit positions for the duration of their careers. Since union dues are composed of a percentage of employee base pay (excluding tips) and because union members who benefit the most are those who stay at the same job for long periods of time, a hotel was not the model employer on which the union movement would theoretically wish to concentrate its efforts. If you worked in the hospitality industry, this made your life easier, because instead of organizing hotel or restaurant employees, the union movement focused on "heavy labor," the skilled and semiskilled employees of America's factories. This has changed.

With the decline in manufacturing, the relevance of the hospitality industry to organized labor grew. Indeed, part of what makes the industry so appealing is that you can't outsource your jobs or move your hotels overseas. Most of the "great hotels" in large American cities today are organized, including nearly all of New York's large, prestigious hotels. A strong union presence is also found in Boston; Chicago; Los Angeles; San Francisco; Washington, D.C.; Las Vegas; Philadelphia; and Honolulu. Since the jobs are staying put, the hospitality industry is now a priority, if not the holy grail for the future of the labor movement. This chapter explains the state of union-management relations in the hospitality industry. Chances are, if you work or plan to work in the hotel industry, you are going to have to deal with either a union campaign or a unionized workforce, and so you will need to know what you can and cannot do. We begin with a brief overview of the law. We then explain traditional organizing as compared with card check or neutrality agreements and how to identify and deal with them at your hotel or resort. We then provide a description of the 2006 negotiations and the union split that followed. Finally, we provide practical advice for those of you who are living with a union, have experienced union organizing, or simply wish to remain union free. 


\section{The National Labor Relations Act}

The first thing you must realize is that union organizing and activities are protected by law, and the law is evolving. The National Labor Relations Act (NLRA) provides employees with the right to organize and to engage in protected, concerted activity, which means two or more employees acting together. This activity is protected if the issues concern wages, hours, or terms and conditions of employment. Thus, two employees who walk out of a nonunion hotel's kitchen because it is too hot are protected. It is unlawful to interfere with employees' organizing rights. Thus, as an employer, you may not refuse to hire employees, fire, or discipline them because they want to form a union. You are also prohibited from forming company unions (unions that are controlled by or answer to management). Most hotel organizing in the twenty-first century has been the result of efforts by large international unions as opposed to small local or regional groups.

\section{Traditional Organizing Drives}

The typical organizing approach under the "old-fashioned" method involves a union targeting a particular company from the outside. In that situation, the union begins by selecting a possible target, assessing employees' interest in organizing, identifying the issues that concern employees, and then contacting the employees to begin the communication process. Other times, employees may start organizing from within and then seek out a union for representation. Regardless, once contact is made between the union and the employees, the union campaign begins in earnest. The contact may come in the form of a "blitz" as the union bombards the employees with information, or a slow buildup of support. In rarer situations, the union may send their members to apply for jobs in a "Trojan horse" technique. The applicants' real reason for applying for work is to gain access to other employees. This method, referred to as salting, may strike you as unfair, but it is protected by law. Even if an applicant openly admits to you in his job interview that he is applying for an open position so that he can organize your workforce on behalf of a union, you cannot decline to hire him on that basis. ${ }^{1}$ Another method for organizing is to enter your property and hand out authorization cards (referred to as "hand billing") or set up picket lines at the entrances and exits to your property for the same purpose. All of these approaches fit within the traditional method of organizing because they all culminate in a governmentmonitored election at your hotel or resort.

The NLRA sets forth the laws regulating this traditional form of employee organization, which

follows the critical path shown in Figure $30.1 .^{2}$ Under those rules, before any labor organization can be 
certified as the exclusive bargaining representative for any group of your employees, the employees in that group, called a bargaining unit, vote for or against union representation in a secret-ballot election monitored by the National Labor Relations Board (NLRB). In most cases, the NLRB seeks to schedule such an election approximately four weeks after the union initiates the process by filing a representation certification petition, also known as an "RC petition." The time period for election may be extended if you as the employer contest the bargaining unit or if other contested issues must be decided by the NLRB. Regardless, the period between RC petition and election provides the union and you as the employer with an opportunity to present your respective positions to the employees eligible to vote.

Under the NLRB rules, a union needs a minimum of 30 percent of your eligible employees to have signed authorization cards before an RC petition may be filed and a secret ballot election scheduled. As a practical matter, however, most unions will not file an RC petition unless at least 60 percent of the employees have signed cards. To prevail in the election, the union needs a simple majority of those who actually vote, not a majority of those eligible. Thus, if 50 of your employees are in the proposed bargaining unit, but only 21 vote, the union needs only 11 votes to win. The employer wins in the event of a tie.
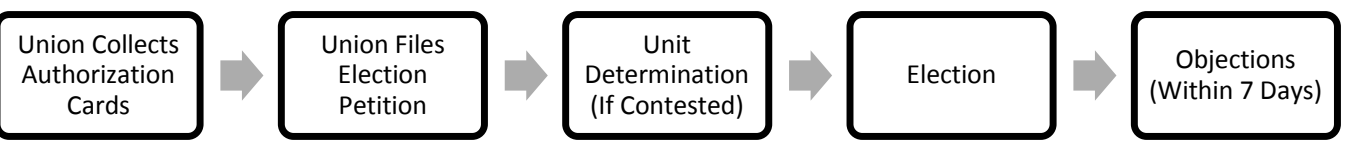

Certification of Results

\section{Figure 1 Election Timeline}

Both sides are free to campaign prior to the election, and most of the - time they do so with vigor. The period between the time the RC petition is filed and the election is held is often referred to as the "campaign period" or "critical period." During this time, the law prohibits employers from using certain tactics. During the "critical period" you may not threaten, interrogate, make promises to, or engage in surveillance of any of your employees. In addition, you may not solicit grievances from or confer benefits on your employees. If an employer violates these rules, the NLRB may either order the election to be rerun or issue a bargaining order (meaning the union is in even if you won the election). You may, however, attempt to persuade your employees to vote against the union, typically by 
informing employees of their rights and the consequences of voting for or against the union. Most employers engage in a multiweek campaign where they communicate with employees using e-mails, letters, speeches, videos, group meetings, campaign materials, and one-on-one conversations. In most campaigns, each week has a theme. For example, during the first week, you might explain that union promises of increased pay or benefits are not trustworthy because the company-not the union-pays for wages and other benefits. In this way, you illustrate that the union cannot guarantee anything that it claims it will do. During the second week, you might educate the employees about strikes and emphasize that employees who are on strike receive no pay and no health insurance, and that they may not get their jobs back when the strike ends. In the third week, you may discuss the issue of union dues and how the money is spent. During the final week, employers often explain that the union's claim of enhanced job security is a myth because unions cannot prevent or have any effect on economic layoffs, and further that employers can still terminate employees who violate company polices or rules. In addition, throughout the campaign, you may focus on the union's reputation and other issues specific to the parties and the local area.

Figure 30.2

Staying Lawful During the Critical Period

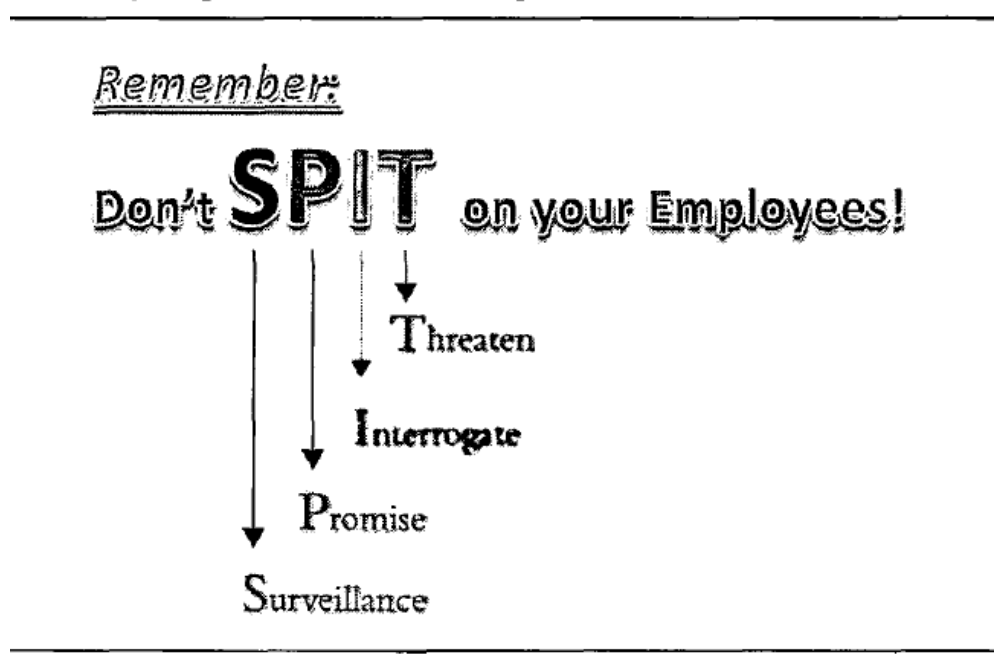

According to management-side labor lawyers, you should carefully diagnose the reasons your employees may be interested in unionization, and then address the root of the problem in your campaign. According to Arch Stokes, a labor lawyer based in Atlanta, Georgia, "the number one reason for unionization is a perceived lack of leadership. If you want to remain non-union, make sure your managers and supervisor are real leaders of men and women. It's more important than wages and 
benefits." Well-planned and carefully implemented antiunion campaigns culminating in secret-ballot elections have led to employers succeeding in defeating unions in the majority of elections.

Not surprisingly, many unions are skeptical of the traditional secret-ballot election. Union advocates claim that employers win secret-ballot elections because employers illegally threaten, intimidate, and terminate employees who favor the union. Unions point to the numerous unfair labor practice charges filed against employers as well as anecdotal evidence of unlawful employer behavior.

\section{Card Checks and Neutrality Agreements}

Regardless of the reason unions lose more elections than they win, one thing is clear: Many unions including UNITE HERE (the union representing the largest number of hotel employees) no longer wish to organize under the traditional NLRB election rules. In fact, as one organizer stated: "[W]e will never go to an NLRB election again. ${ }^{3}$ Instead UNITE HERE's strategy is to organize using card-check and neutrality agreements instead of NLRB-supervised elections. To accomplish this objective, unions need to have some leverage over employers to pressure them into signing card-check and neutrality agreements.

Although neutrality agreements come in several forms, the common denominator for all of them is that employers agree to stay neutral with regard to the unions attempt to organize the workforce in exchange for the union promising labor peace. ${ }^{4}$ Some agreements simply state that the employer will remain neutral with no other language, while other agreements contain more specific provisions. ${ }^{5}$ For example, UNITE HERE's standard agreements clearly state that employers "will not communicate opposition" to the union's efforts.

Neutrality agreements commonly provide the union with access to employees in the form of a list of their names and addresses (and sometimes telephone numbers), as well as permission to come onto company property during work hours for the purpose of collecting signed authorization cards. This provision diverges from the guidelines set up by the NLRB and the courts, under which an employer has no obligation to provide the union with such sweeping access to its employees, and may actually be prohibited from doing so.

Finally, most neutrality agreements also include a card-check provision, which requires the employer to recognize the union if a majority of bargaining-unit employees sign authorization cards. Under a card-check agreement, the employees do not engage in a secret-ballot election. Instead, the employer recognizes the union if it presents the company with a majority of signed authorization cards. 
From an employer perspective, the obvious problem with card-check and neutrality agreements is that it takes away your ability to campaign against the union.

\section{The Effect of Neutrality Agreements}

Neutrality agreements have radically changed the landscape of union organizing. One study conducted in the late 1990s examined 170 private-sector "union campaigns" in which the employer and the union agreed to neutrality with a card-check provision. With the aid of such agreements, the union prevailed in 78.2 percent of those 170 campaigns. ${ }^{6}$ In contrast, the unions' success rate in contested NLRB elections during the same time period was 46 percent. While the difference between these two numbers seems substantial, it actually understates the true value of the card-check and neutrality agreement to unions. Given the reality that no union will petition for an election unless they have well over 50 percent support of the prospective bargaining unit, one can infer that when a union loses a secret-ballot election, it initially enjoyed majority support and then lost the majority support by the time of the vote. Under a card check-neutrality agreement, the union would have won these organizing campaigns. Thus, almost every election where the employer won (54 percent) would have resulted in a union victory if there had been a card-check agreement.

What this means for you as an employer is that if you want to avoid becoming unionized, be sure not to sign a card-check or neutrality agreement. As set forth below, however, the decision is not that simple.

\section{To Sign or Not to Sign? That Is the Question}

So why would you ever accede to a card-check and neutrality agreement in the first place? The short answer is that you may sign one because it is in your best interests to do so-either to obtain an affirmative benefit, or more likely to protect your company from the union's corporate campaign against you. Observers who believe that unionization is never in the employer's best interest would likely be puzzled by this statement, but signing a neutrality agreement is, in fact, in the employer's best interest in some situations. One example occurs in some municipalities that have instituted labor peace agreements that required neutrality for employers that wish to obtain building permits or even to operate in the particular jurisdiction. As another example, a union may even buy a hotel and make a neutrality agreement a condition for any operator wishing to manage that property. Finally, an employer might sign a neutrality agreement because the union is selling something that the employer wishes to buy. 
Perhaps the greatest bargaining chip that unions have to offer an employer in exchange for neutrality is labor peace. To sell peace, though, the union needs the ability to create unrest. At the turn of the century, UNITE HERE - forged a strategy that allowed it to create unrest for the hotel industry to afford it the opportunity to peddle peace. The union employed this tactic ${ }^{\wedge}$ with tangible results in summer 2006.

\section{Union Summer 2006}

Most of the unionized hotels in the major cities in the United States and Canada are part of citywide employers' associations that bargain as a multiemployer groups. The contracts that emerge from these negotiations are referred to as area or industry-wide agreements and cover all the hotel employers in the association. In addition, some properties who are not part of the multiemployer group sign what are referred to as "me-too agreements," which bind the nonassociated by the area agreement. Traditionally, the contracts $J$ in the major cities expired in different years because the older hotel union, HERE, did not have the resources to negotiate on several fronts at the same time. Likewise, the hotel companies found it too cumbersome to juggle multiple negotiations for their properties in several cities simultaneously. Thus, both sides were agreeable to having the contracts for each market expire in different years.

For the series of negotiations prior to 2006, the merged union, UNITE HERE, changed its strategy. Specifically, it sought to have all the contracts in a number of large cities expire in the same year. UNITE HERE did not, of course, announce this strategy to employers. In spring 2000 the union and the New York employer's association extended to 2006 their contract, which had been set to expire in 2001. Then, in 2003, the union and the associations in Chicago and Boston signed three-year contracts. Next, by agreeing to short contracts, or no contracts at all, the union made sure that, in addition to New York, Boston, and Chicago, the contracts in Honolulu, Los Angeles, San Francisco, Detroit, and Toronto all expired in 2006.

Having these contracts expire in 2006 was not completely successful, nor was it without a significant amount of rancor. First, the employer association in Washington, D.C., refused to agree to a short contract. The Washington, D.C., contract, signed in 2004, expired in 2007. Similarly, the San Francisco contract expired in 2004 and the employers refused a two-year contract. The union called a strike, and the employers issued a lockout. Even after the work stoppages concluded, the union issued a boycott of certain unionized hotels. Consequently, there was no contract signed until summer 2006. Despite these disruptions, the union was able to align most of its major city contracts to end in 2006. 
Having contract negotiations in several cities allowed the union to pursue its twenty-firstcentury strategy. Instead of focusing on the property or even the city level, UNITE HERE wanted to negotiate and apply pressure at the corporate level. That was the reason it wanted to negotiate in all the major cities at one time and to negotiate neutrality agreements. That is precisely what the union did in 2006.

Since neutrality agreements are merely permissive subjects of bargaining (as opposed to mandatory subjects), UNITE HERE could not insist that the hotels discuss this form of organizing. Instead, the union had to offer something to employers-namely, labor peace. Hotels were faced with a choice; buy peace in exchange for neutrality or go to war. To get hotels to purchase peace, the union had to make realistic its threats of labor unrest.

To embark on that approach, the union first needed to ensure that it had the financial resources and the member support to strike. The union had worked hard to achieve both of these goals. For example, in June 2004, the union's New York leadership proposed that members agree to payroll deductions of $\$ 10$ per week to create a strike fund. The membership overwhelmingly agreed, and by the time the New York contract expired in 2006 the union had accumulated \$26 million. The union also did a masterful job of getting its members to buy into the necessity of the cause. For example, speaking to the Hotel Trades Council's 2006 Contract Convention on June 10, 2004, union head Bruce Raynor told his audience: "You and your members are about to become members of the biggest and baddest union on the planet!... You fight one of us, you'll fight all 500,000 of us." John Wilhelm expressed similar sentiments when he told the council: "You don't permit the hotels to divide you by job, by hotel, by race, by age, or by any other factor, and you're not going to let them divide you by city. In fact, in 2006 you are going to divide and conquer them!"

From the time it began its plan to have numerous contracts expire during the same summer, UNITE HERE's strategy was clear: Begin corporate campaigns. Instead of negotiating against one employer association with numerous properties, UNITE HERE set up a system where it negotiated against one operator with hotels throughout the country. The union then set up an "us versus them" strategy. Smaller operators were encouraged to stay out of $\mathrm{N}$ negotiations with the large operators and invited to sign "me-too" agreements. The November 1, 2005, issue of Hotel Voice contained the following quote: "The hotels that sign a "me-too" agreement are the good guys. The hotels that sign the Hotel Association's Mutual Assistance Pact are trying to pick a fight with the union and their employees." 
Mutual assistant pacts would require properties to lock out employees if any of their sister properties went out on strike. Signing a mutual assistance agreement put a hotel in line to participate in a prospective war. A me-too agreement, however, meant an employer could stay on the sidelines of the potential war and simply benefit (or suffer) from the agreement negotiated by the association. Most operators decided to sign me-too agreements.

With many small operators on the sidelines, the union focused on major operators. The first major strategic decision was to attempt to split the chains. In this instance, the union exercised its right to exclude Hilton from the industry-wide bargaining agreement, based on accusations regarding Hilton's labor record. Peter Ward, president of the New York Hotel Trade Council, explained: "Our reasons for isolating Hilton are well known. We firmly believe that a separate contract with the Hilton Corporation is necessary because of its record in dealing in bad faith with the union and with its employees." Separating such a large operator from its cohorts caused unrest among the operators and forced Hilton to negotiate on its own. The employers' associations were forced to decide whether to wait to see what would come out of the Hilton negotiations or to try to cut a deal before UNITE HERE's Hilton negotiations got messy. Moreover, regardless of the employers' desires, the union had substantial control over the sequence of negotiations. In other words, the Union could focus on Hilton and ignore the association for a period of time. For example, in New York, the association and the union reached an agreement before Hilton did so, while in Chicago, the opposite occurred.

\section{The Union Pits Owners against Operators}

The union's divide and conquer strategy did not stop with operators. The union also used hotels' distinctive ownership structure (discussed in Chapter 17) to its advantage. Since operators rarely own the hotels they manage, the interests of the owner and the operator conflict in many situations. For example, an owner of a unionized hotel has no interest in fighting for the right of new (competing) hotels to be nonunion. Indeed, the unionized owner may want the new operator to agree to a neutrality agreement to level the playing field in the area of labor costs and work rules. Even owners with different goals might not form a united front, as short-term investor- owners would have a different perspective from long-term buy-and-hold owners. Owners soon hired their own counsel and bargained alongside, but not always consistent with their operator agents.

As operators separated from each other and owners separated from operators, the union remained united. By November 2006, the union could call or threaten to call strikes against one operator in all seven cities or even against several operators. The multiple-strike threat was viable 
because the union had employee support, a well-financed strike fund, and strong communication. The companies knew that the employees possessed the will to strike if a strike was called by the union leadership. A multicity strike was particularly daunting for employers because hotel operators could not bring in members of management from other cities to do strikers' work. More important, the companies knew that the me-too signatories would not support operators who were suffering from a strike. Instead, the me-too signatories would actually take the available hotel and convention business. To complete the "perfect storm" scenario, the hotel industry was in the midst of an upswing and was finally getting over the negative business effects of 9/11. Summer 2006 was, from a financial standpoint, the best summer for hotels since the watershed year of 2000. Simply put, the operators could not let labor unrest prevent the industry from enjoying what looked to be one of its most successful summers ever. With most if not all of its pieces in place, the union's real ability to wage war allowed it to sell peace.

The union did, in fact, sell peace. Except in San Francisco, which had endured the strike, lockout, and boycott of 2004, the summer 2006 negotiations resulted in no strikes, no lockouts, and no labor strife at all. Hilton, once referred to as evil, became the preferred hotel company for UNITE HERE. By the end of the year, New York, Chicago, Los Angeles, San Francisco, Honolulu, and Toronto all signed agreements. Soon after, agreements were reached in Boston and Detroit. The union declared victory; a conclusion with which operators, owners, and management lawyers seemed to agree.

What remains unclear today is what the union really gained in exchange for the peace with regard to neutrality. In New York, the issue of neutrality was irrelevant because all new properties operated by any member of the association (including me-too signatories) were covered by an existing neutrality agreement. This was not the case in other cities, however, where the union obtained neutrality agreements for new hotels that would be owned or operated in the future by existing employers. While a few traditionally nonunion properties have unionized since 2006, UNITE HERE did not make significant organizing gains through its peace-for-neutrality strategy and thus, the unions are turning to the government for help through proposed legislation.

\section{Labor Law Reform}

Unions' organizing hopes revolve around the passage of the Employee Free Choice Act (EFCA). EFCA requires the NLRB to recognize a union if a majority of the employees signed authorization cards, increases the money owed to employees who were disciplined or discharged for trying to organize a union from straight back pay to triple back pay, imposes fines of up to $\$ 20,000$ for certain unfair labor practices, and requires parties who cannot agree on a contract after 90 days of negotiations to submit 
their issues to "interest arbitration," a process whereby an arbitrator decides the terms and conditions of employment.

On March 2, 2007, the House of Representatives overwhelmingly passed EFCA. Because President Obama, a sponsor of the bill, was elected with a 60-40 Senate majority, many thought EFCA would pass in the first 100 days. The economic crisis, health care reform, and other legislative initiatives, however, derailed EFCA. Moreover, employers mobilized and argued that free choice and eliminating secret-ballot elections were inconsistent principles. Soon, some prominent Democrats were questioning the bill. After the 2010 mid-term elections, EFCA has left the national debate. However, even if it is not revived, labor reform appears possible.

While the National Labor Relations Act does provide for secret ballot elections, many other aspects of union organizing are the products of NLRB decisions and rulemaking. The NLRB is made up of five members appointed by the president for five-year terms. The general rule is that the party in power will hold a 3-2 majority. Now that the Obama board has a majority, there may be labor law reform without legislation. For example, the NLRB currently attempts to hold elections within approximately 30 40 days of the petition being filed. The NLRB could change this to 20,10 , or even 5 - days. Elections occurring within such a short time period would fundamentally change organizing. Currently, employers do not have to allow unions on their properties. The NLRB could change this and require employers to provide access for unions. These are just two examples of what the NLRB could do to shift the balance of power in the labor-management relationships.

Whatever the source-legislative action or NLRB rule-making-labor law reform may be on the horizon. Accordingly, you should expect it to be easier for unions to organize your workforce in the coming years.

\section{How to Address Union Issues for Nonunion and Union Hotels}

Union issues are a fundamental component of the hospitality industry. Hotels that are unionfree generally want to stay that way. Unionized hotels must learn to live and work with the union. ${ }^{7}$

Nonunionized Hotels: Employers seeking to remain nonunion should follow a few simply principles. First, if the city has a strong union presence, you should ensure that you offer compensation and benefits similar to or better than that of the union hotels. Since most employers contend that it is union work rules and not compensation and benefits that makes unionization untenable, matching union wages and benefits should not be daunting. Second (and most important), you must have effective leadership and a positive employment culture. Concerns about leadership and fairness are 
what drive union organizing campaigns. If your employees believe your managers and supervisors do not act with integrity (see Chapter 31) and are not acting in the employees' best interest, they will go outside your hotel and seek a third party to represent them. However, if your employees believe in your leadership team and the employment culture they have created, your employees will see no need for collective power and no need to pay someone to speak on their behalf.

If you have signed a card check and neutrality agreement, your employment culture is even more vital to a remaining nonunion, for two reasons. First, you cannot actively campaign against the union because you have agreed to remain "neutral." Thus, you must let your strong leadership, employment culture, and integrity as an employer speak for itself. Second, the union might get a majority of eligible employees to sign cards before you even know the union is organizing, at which point you have to recognize the union before you can even react.

In sum, the best way to avoid unionization is to be proactive, not reactive. Anticipate your employees' needs and concerns. Fix problems before they fester. Remove and replace poor or mediocre managers with effective leaders. Union prevention is simply good leadership practiced 24 hours a day, 365 days a year. If you follow these principles and are faced with a union- organizing effort, you will be well-positioned to succeed in your campaign with the help of an experienced professional to guide you through the legal labyrinth.

Unionized Hotels: Hotels that are already unionized face a different set of challenges. If your employees are represented by a union, you can choose to have either a cooperative or an adversarial relationship with your employees and their union. Our observation is that establishing a good working relationship with the union is essential to a successful union hotel. A union's business model encourages cooperation and good communication with its members' employer because conflict costs the union more time and money than harmony does. Thus, most union representatives assigned to your hotel (often called "business agents") will seek quick and efficient solutions to problems that could become grievances and ultimately arbitrations. You should encourage frequent communication with these representatives and creatively seek solutions to your disputes. That is not to say, however, that you should roll over every time the union makes a demand or opposes discipline against one of your employees. Essential to the operation of your unionized hotel is an experienced and tough HR professional who knows every detail of the collective bargaining agreement with the union and is prepared to enforce your contractual rights when necessary. That person also needs to be fair and open to creative solutions within the context of your contractual rights and obligations under the collective 
bargaining agreement. Ideologues who see the world as black and white rarely do well in this position. The most successful union hotels are those that resolve employee conflicts at the lowest possible level.

The cycle of collective bargaining with a union is an especially daunting aspect of a unionized hotel. Most collective bargaining agreements have a term of three years or more. As a collective bargaining agreement nears the end of its term, the union will invariably start to file grievances and make other demands in order to gain leverage at the bargaining table. In other words, the union will often create artificial conflict and then trade resolution of that conflict for some benefit during negotiations. Your managers need to be aware of this dynamic and be extra vigilant during these times to prevent problems before they arise (or before they are manufactured). A strong employment culture and good employee relations will discourage many of your employees from participating in this theatrical exercise.

Finally, collective bargaining itself is usually a long, difficult, and expensive process. Unions in the hotel industry are typically represented at the bargaining table, by experienced labor negotiators who have immediate access to competent labor lawyers. Rarely will the union's proposals reflect only the interests of your employees, but will also reveal a regional or even national agenda. You might even be the target of picketing or a strike during negotiations, often as part of the union's larger strategy and not in response to anything you did. For all of these reasons, you should hire an experienced labor professional and carefully prepare for collective bargaining negotiations and all of the contingencies associated with them.

\footnotetext{
${ }^{1}$ N.L.R.B. v. Town \& Country Elec. Inc., 516 U.S. 85 (1995).

${ }^{2}$ For the full text of the NLRA, see: www.nlrb.gov/nlrb/legal/manuals/rules/act.asp.

${ }^{3}$ M. Hughlett, "Hotel Worker's Union in St. Paul, Minn., Plans New Tack in Organizing," Hotel Online, www.hotelonline.com/neo/news/2001_June_22/k.SPH.993243589.html, June 20, 2001 (quoting Jaye Rykunyk, head of H.E.R.E. Local 17).

${ }^{4}$ For a discussion of neutrality agreements, see A. E. Eaton and J. Kriesky, "Union Organizing Under Neutrality and Card Check Agreements," 55 Industrial and Labor Relations Review 42(48): 8-9.

5 Ibid., p. 9.

${ }^{6}$ Ibid., p. 15.

${ }^{7}$ For example, see A. Eaton, T. Kochan, R. McKersie, and P. Adler, Healing Together: The Labor-Management Partnership at Kaiser Permanente (Ithaca, NY: Cornell University Press, 2009).
} 